Vol. 24, No. 4, pp. 424 437, 2021.

\title{
Recent Advances in High Temperature Electrolysis Cells using $\mathrm{LaGaO}_{3}$-based Electrolyte
}

\author{
Seokhee Lee ${ }^{1}$, Sang Won Lee ${ }^{1}$, Suji Kim¹, Tae Ho Shin ${ }^{1 \uparrow}$ \\ ${ }^{1}$ Energy and Environmental Division, Korea institute of Ceramic Engineering and Technology, \\ Jinju-si, Gyeongsangnam-do 52851, Republic of Korea.
}

\section{$\mathrm{LaGaO}_{3}$ 기반의 전해질을 이용한 고온 수전해 기술의 최신 동향}

\author{
이석희 ${ }^{1}$, 이상원 ${ }^{1}$, 김수지 ${ }^{1}$, 신태호 ${ }^{1 \dagger}$ \\ 1한국세라믹기술원
}

(Received December 3, 2021; Revised December 25, 2021; Accepted December 27, 2021)

\begin{abstract}
s
High temperature electrolysis is a promising option for carbon-free hydrogen production and huge energy storage with high energy conversion efficiencies from renewable and nuclear resources. Over the past few decades, yttria-stabilized zirconia (YSZ) based ion conductor has been widely used as a solid electrolyte in solid oxide electrolysis cells (SOECS). However, its high operation temperature and lower conductivity in the appropriate temperature range for solid electrochemical devices were major drawbacks. Regarding improving ionic-conducting electrolytes, several groups have contributed significantly to developing and applying $\mathrm{LaGaO}_{3}$ based perovskite as a superior ionic conductor. $\mathrm{La}(\mathrm{Sr}) \mathrm{Ga}(\mathrm{Mg}) \mathrm{O}_{3}$ ( $\mathrm{LSGM}$ ) electrolyte was successfully validated for intermediate-temperature solid oxide fuel cells (SOFCs) but was rarely conducted on SOECs for its high efficient electrolysis performance.

Their lower mechanical strengths or higher reactivity with electrode compared with the YSZ electrolysis cells, which make it difficult to choose compatible materials, remain major challenges. In this field, SOECs have attracted a great attention in the last few years, as they offer significant power and higher efficiencies compared to conventional YSZ based electrolysers. Herein, SOECs using LSGM based electrolyte, their applications, high performance, and their issues will be reviewed.
\end{abstract}

Keywords: lanthanum gallate, solid oxide electrolysis cells, perovskite, high temperature electrolyser

${ }^{\dagger}$ Corresponding Author: ths@kicet.re.kr 


\section{1. 서론}

수소 에너지는 재생에너지의 확대에 따른 전력생산의 간헐적 에너지 저장 불균형문제와 기존 대용량 에너지 저장장치 (Energy Storage System, ESS)의 용량과 저 장 시간의 한계를 극복할 수 있는 미래 청정에너지 통합 시스템의 잠재적인 대안이다. 정부의 수소경제 활성화 를 위한 수소에너지 산업은 수소의 생산부터 저장, 운송 및 활용까지의 전후방 관련 산업의 유기적 연결이 필요 하며, 이러한 수소에너지 산업은 2050년 탄소중립 배출 제로를 실천하기 위하여 재생에너지와 연계되어 이산화 탄소의 배출이 없는 청정 수소의 생산 기술 확보를 필요 로 하고 있다. 전 세계는 지구의 이상기온 현상을 막기 위해 지구 온난화의 주원인인 온실가스 배출을 엄격히 제한하고 2050년까지 각국의 탄소중립 목표를 설정하 여 화석연료 에너지 시스템에서 청정 수소 에너지 시스 템으로 전환을 선언하고 관련 산업 육성에 박차를 가하 고 있다.

앞서 언급한 바와 같이 태양광, 풍력 등의 재생에너지 는 전력 생산이 자연환경에 영향을 간헐적으로 받기 때 문에 전력 생산의 예측이 어렵고 변동폭이 크기 때문에
전력망에 직접 연결하는 것이 어려운 한계가 있다. 이러 한 측면에서 재생에너지와 연계되어 청정 수소를 생산 하는 수전해 기술은 잉여 전력 에너지를 수소 화학에너 지로 변환 저장하여 상대적으로 높은 저장 전력 용량과 장시간 전력 에너지 저장이라는 장점으로 주목을 받고 있다. 따라서, 수소는 미래에 탄소배출 제로의 중립 실 현을 위한 필수적인 에너지 변환 매체로 인식되며 고효 율 수전해 수소 생산 기술이 현재 크게 각광을 받고 있 다. 수전해 기술은 순수한 물을 직류 전력을 공급하여 수소와 산소로 분리하는 전기분해 기술로 크게 알카라 인 수전해( $\mathrm{AEM})$, 고체고분자전해질(PEM), 그리고 고 체산화물(세라믹) 전해질을 이용하는 고온 수증기 전해 SOEC (Solid Oxide Electrolysis Cell) 기술로 구분된 다(1) (Fig.1). 이온 전도성 세라믹을 전해질로 사용하는 $\mathrm{SOEC}$ 는 고온 작동으로 인한 빠른 전극 계면 화학반응 때문에 백금 등의 귀금속 촉매 의존도를 낮출 수 있으며 에너지 저장-변환 매개체로 수소 외에도 이산화탄소, 암모니아, 메탄 등의 화학 에너지 변환매개체의 다양성 에 대한 장점을 갖고 있다.

그러나, 현재 $\mathrm{SOEC}$ 는 기존 고체산화물연료전지 (SOFCs; Solid Oxide Fuel Cells) 구성 소재를 동일
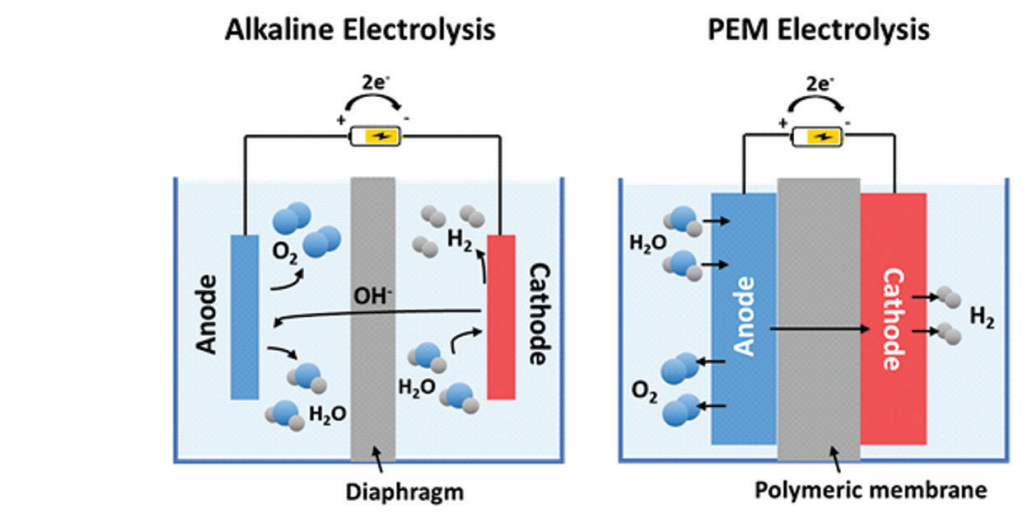

Solid Oxide Electrolysis

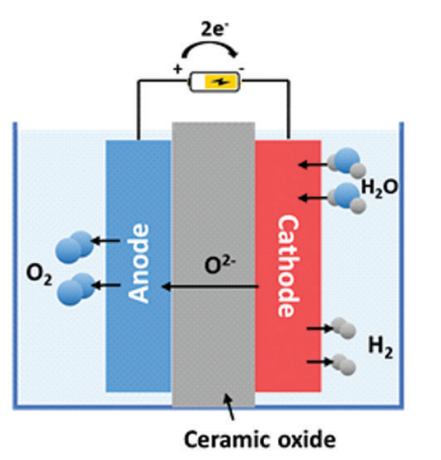

\begin{tabular}{|l|l|}
\hline Anode & $4 \mathrm{OH}^{-} \rightarrow 2 \mathrm{H}_{2} \mathrm{O}+4 \mathrm{e}^{-}+\mathrm{O}_{2}$ \\
\hline Cathode & $4 \mathrm{H}_{2} \mathrm{O}+4 \mathrm{e}^{-} \rightarrow 4 \mathrm{OH}^{-}+2 \mathrm{H}^{+}$ \\
\hline
\end{tabular}

$2 \mathrm{H}_{2} \mathrm{O} \rightarrow 4 \mathrm{H}^{+}+4 \mathrm{e}^{-}+\mathrm{O}_{2}$

$\mathrm{O}^{2-} \rightarrow 1 / 2 \mathrm{O}_{2}+2 \mathrm{e}^{-}$

Cathode $4 \mathrm{H}_{2} \mathrm{O}+4 \mathrm{e}^{-} \rightarrow 4 \mathrm{OH}^{+}+2 \mathrm{H}^{+}$

$4 \mathrm{H}^{+}+4 \mathrm{e}^{-} \rightarrow 2 \mathrm{H}_{2}$

$\mathrm{H}_{2} \mathrm{O}+2 \mathrm{e}^{-} \rightarrow \mathrm{H}_{2}+\mathrm{O}^{2-}$

Fig. 1. Operation principles of alkaline, PEM and SOEC for water electrolysis reproduced from Sapountzi et al. Proc Prog. Energy Combust. Sci. 2017;58:1-35, with permission of Pergamon Press (1) 
하게 활용하여 가역반응 하는 수준의 기초적 단계 연 구가 대부분이며, 이에 사용되는 산소이온전도성 기 반 고체전해질은 $\mathrm{SOFC}$ 와 동일하게 Yttria-stabilized Zirconia (YSZ) 세라믹 소재를 널리 이용하고 있어 $\mathrm{SOFC}$ 와 동일한 소재 이슈의 관점을 공유하고 있다. 지 르코니아 기반의 전해질 소재를 사용하는 경우 일반적 으로 $800^{\circ} \mathrm{C}$ 이상의 높은 작동 온도가 요구되게 되며 높 은 작동 온도로 인해 단위 셀 구성 소재의 열화를 촉진 할 뿐만 아니라, 이러한 전기화학적 고온 환경은 스택 을 구성하는 금속 기반의 주변 부품의 열화를 촉진하여 장기 내구성을 저하시키는 근본적인 요인이다. 따라서, $\mathrm{SOEC}$ 는 물론 $\mathrm{SOFC}$ 연구분야에서 동일하게 상대적 높 은 효율을 유지하는 범위에서 작동 온도를 낮출 수 있는 전해질 소재에 대한 연구가 지속적으로 진행되고 있다. 그중 1994년 Ishihara에 의해 보고된 $\mathrm{Sr}, \mathrm{Mg}$ 이 동시 도 핑 된 $\mathrm{LaGaO}_{3}$ 페롭스카이트 (LSGM, $\mathrm{La}(\mathrm{Sr}) \mathrm{Ga}(\mathrm{Mg})$ $\mathrm{O}_{3}$ )에서 산소 이온 전도성이 우수한 것이 보고되었고, 이 후 LSGM 전해질을 이용한 고성능 SOFC 및 SOEC 의 결과가 보고되고 있다. 하지만, LSGM은 낮은 기계 적 강도와 고온 제조공정에서의 전극 물질과의 화학적 반응에 따른 호환성 문제들로 고성능에도 불구하고 상 용화에 어려움을 겪고 있다. 본 논문에서는 LSGM을 활 용한 $\mathrm{SOEC}$ 의 일반적인 개요 및 고성능 특성들을 소개 하고, 더 나아가 현재 적용되는 $\mathrm{LaGaO}_{3}$ 계 전해질의 고 이온 전도성 소재의 전망과 응용 확장성 등을 살펴보고 자 한다.

\section{2. 셰라믹 고온 수전해 연구의 배경}

물을 직접분해하여 수소와 산소를 생산하는 수전해 기 술은 1800년에 Nicholson과 Carlisle 이 처음으로 개념 을 정리하였고, 1820년에 Faraday가 전기화학적 이론 으로 정립하여 1934년에 전해(전기분해, 'electrolysis') 로 소개되었다. 이후 Nernst에 의해 $15 \% \mathrm{yttria}$ 가 도핑 된 YSZ 고체전해질을 처음으로 이용하여 수소와 산소 를 고온에서 분리하는 실험을 통해 고온 수전해 개념으 로 $\mathrm{SOEC}$ 연구가 시작되었다. $800^{\circ} \mathrm{C}$ 이상에서 이온 전

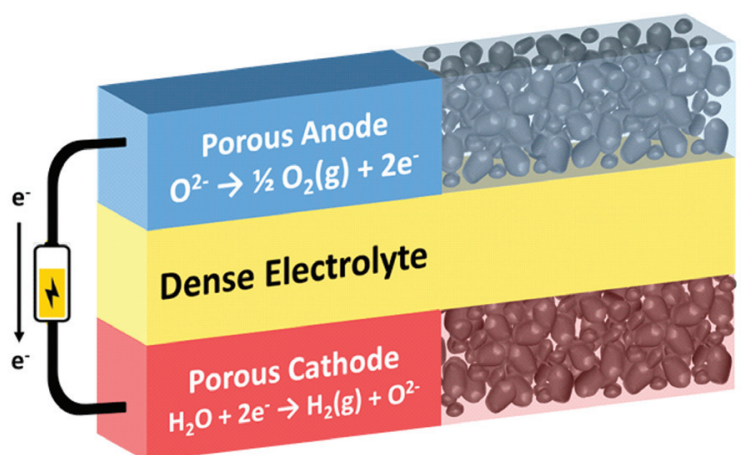

Fig. 2. Scheme of a SOEC cell under electrolysis mode

도 특성이 있는 YSZ와 같은 순수 산소 이온 전도성 세 라믹을 전해질로 사용하여 고온에서 수증기(물)를 전기 분해하는 $\mathrm{SOEC}$ 의 기본 개념과 전극 반응은 Fig. 2 와 같다.

$\begin{array}{ll}\text { Anode (산화 전극): } \mathrm{O}_{2}-\rightarrow 1 / 2 \mathrm{O}_{2}+2 \mathrm{e}^{-} & \text {식 (1) } \\ \text { Cathode (환원 전극) }: \mathrm{H}_{2} \mathrm{O}+2 \mathrm{e}-\rightarrow \mathrm{H}_{2}+\mathrm{O}^{2-} & \text { 식 (2) }\end{array}$

고온 수전해반응은 비자발적인 산화-환원 반응이고 연료전지 반응의 가역반응으로 전기화학적 산화, 환원 의 기준에 따라 SOFC의 Anode와 Cathode의 구분과 $\mathrm{SOEC}$ 의 Anode와 Cathode의 구분 개념이 상반된 경 우이다. 따라서 기존 $\mathrm{SOFC}$ 구성 소재를 활용하여 가역 반응을 통해 수전해하는 방식에서는 SOFC의 anode 전 극이 SOEC의 cathode와 동일한 구성 소재가 된다. 고 온 수전해 SOEC의 주요 구성 소재는 치밀한 이온 전도 성 전해질과 다공성 전극으로 구성되며 세라믹 전해질 과 전극 특성에 따라 고온에서 작동한다. 고온 수전해 $\mathrm{SOEC}$ 는 고온에서 산소 음이온 전도성 전해질을 사용하 는 경우가 대부분이지만, 최근 수소 양이온 (프로톤, 양 성자) 전도성 페롭스카이트 전해질을 이용하여 $500^{\circ} \mathrm{C}$ 범위의 중저온 $\mathrm{SOEC}$ 에 대한 연구도 활발하다. 알카라 인이나 고분자 형의 저온형 수전해 시스템은 상용화 수 준으로 개발이 되고 있으나 기술적으로 최고의 에너지 효율은 $75 \%$ 로 보고된 바 있다. 반면, 고온 수전해의 가 장 큰 장점은 열역학적으로 높은 효율을 얻을 수 있다는 것에 있으며, 추가적인 외부 열원을 활용할 경우 에너지 효율은 극대화될 수 있다. 


\section{3. 고온 수전해의 열역학적 그찰}

열역학적으로 물 분해 과정은 흡열반응으로 수소생산 량이 많은 반응에서는 흡열 보전에 따른 고온에서의 반 응 시스템이 유리할 수 있으며, 전기분해 셀에서의 불가 피한 줄 히팅 열이 사용될 수 있어 높은 온도에서의 전 력 감소는 유리한 측면이 있다. Fig. 3 는 물전기분해에 있어서 온도에 따른 요구에너지양을 나타낸 것으로 온 도가 높을 수록 전기에너지의 양이 감소하고 열에너지 는 증가하게 된다. 전체 요구 에너지는 작동 온도와 상 관없이 일정하지만, 고온에서는 전극 반응에서의 과전 압이 적고 물 분해의 흡열반응에서의 열 손실과 셀 내부 에서의 줄 히팅 상쇄 등의 유리한 환경적 조건으로 인해 고온 작동의 장점 등이 있다.

$\mathrm{SOEC}$ 의 전극과 고체전해질을 통해 연속적 이온 의 투과에 따른 구성 소재 내부의 전류 흐름은 아래 식 과 같이 줄 히팅(Joule heat)을 발생시키며 이로 인한 thermoneutral voltage의 전압강하는 전해에 필요한 전기에너지 수요를 감소시켜 고온 수전해를 통해 수소 생산 단가의 절감을 기대할 수 있다. 수증기 전해 반응 은 흡열반응이며 주변에서 열을 흡수하기 때문에, 이로 인한 전극 계면에서의 냉각 현상은 반응속도를 늦추고 과전압으로 전해 셀의 전압을 증가시키며 식 (5)에서의

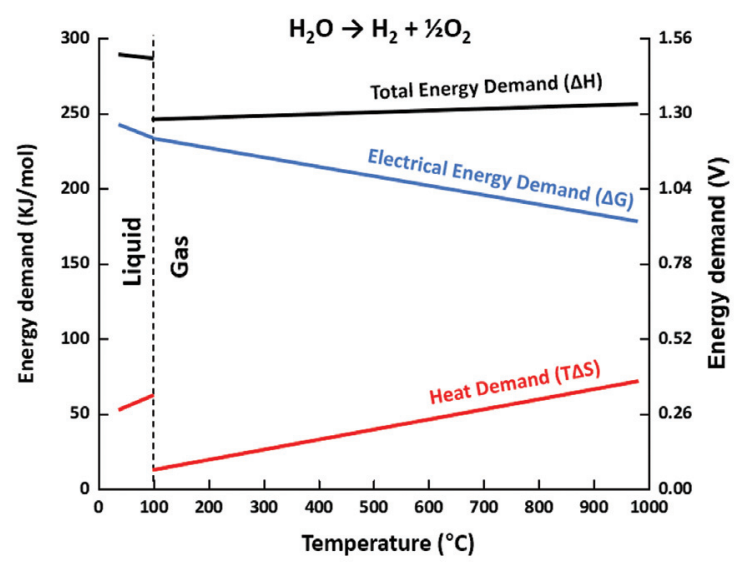

Fig. 3. Thermodynamic for water electrolysis at atmospheric pressure reproduced from Sapountzi et al. Proc Prog. Energy Combust. Sci. 2017;58:1-35, with permission of Pergamon Press (1)
전압과 전류의 곱으로 열을 생성하고 생성된 열이 일정 온도를 유지하기 위한 반응에 필요한 열과 일치할 경우 그 전압은 'thermoneutral voltage'라 한다.

$$
\begin{aligned}
\Delta G & =\Delta H-\Delta S T \\
\Delta G & =-n F E(\text { cell }) \\
V_{\text {th }} & =-\frac{\Delta H_{f}}{n F}
\end{aligned}
$$

$E$ (cell) 은 갈바닉 전기화학 소자의 $\mathrm{EMF}, V_{t h}$ 는 전 압, $\Delta H_{f}$ 는 엔탈피, 전해 반응에 필요한 전체 열에너 지, $\mathrm{n}$ 는 반응에 참여하는 전자 수, 그리고 $\mathrm{F}$ 는 패러 데이 상수를 나타낸다. 따라서, 열역학적으로 열적평 형상태에서 전해 화학반응으로 계산된 고온에서의 전 압은 약 $1.29 \mathrm{~V}\left(900^{\circ} \mathrm{C}\right.$ 기준 $)$ 이며, thermoneutral voltage 기준으로 그 이상의 운전은 줄 히팅을 동반 하는 발열운전 모드로 전기적 효율은 $100 \%$ 보다 낮 아지게 된다. 만약 전극이나 시스템 내부에서 물의 수 증기화 반응을 포함한다면 물의 증발 엔탈피, $H_{\mathrm{evp}}$ 는 $40.65 \mathrm{~kJ} / \mathrm{mol}$ 로 수증기화 반응의 열적 평형에서 의 thermoneutral voltage는 식 (3)에 의해 약 $0.21 \mathrm{~V}$ 가 되며, 고온에서 물의 전해 관련된 모든 반응 (수증 기화 + 물 분해)의 열역학적 열적 평형 전압은 $1.5 \mathrm{~V}$ 가 된다(2). 이는 $1.5 \mathrm{~V}$ 전압을 기준으로 $\mathrm{SOEC}$ 구동의 흡 열-발열 운전 모드에 따라 전력 변환 효율을 $100 \%$ 내 외로 운전 제어가 가능하며, 운전 전압이 열적 평형의 기준 이하인 흡열 운전 환경에서는 수소 생산의 전기 적 변환 효율은 $100 \%$ 이지만 외부 공급 열 환경이 지 속적이어야 높은 전체 에너지효율을 주장할 수 있다. 다만, 스택이나 시스템 레벨에서의 정확한 열적 평형 thermoneutral voltage, 기준 전압의 계산은 구성 부 품, 시스템 내부에서의 모든 열 교환, 열 손실 반응 등 이 고려되어야 한다. 어쨌든 $\mathrm{SOEC}$ 는 상대적으로 고온 작동으로 전기 변환 고효율의 흡열모드 작동 운전에서 외부 열 환경이 존재하므로 유리하며 외부의 추가적 열 환경을 제공하는 융합 시스템에서 수소 생산은 전체 에 너지 측면에서 매우 효율적인 수전해 방식인 것은 분명 하다. 


\section{특 집 ㅍ 이석희, 이상원, 김수지, 신태호}

\section{SOEC 단위 셀 구성}

현재까지의 일반적인 $\mathrm{SOEC}$ 는 $\mathrm{SOFC}$ 와 동일한 구성 소재와 특징을 공유하고 있으며, $\mathrm{SOFC}$ 보다 구성요소 의 장시간 전기화학적 안정성이 중요하게 요구되고 있 다. $\mathrm{SOEC}$ 구성 소재 중에서 가장 중요한 전해질은 화학 적으로 고온에서 안정해야 하며 낮은 전자 전도도를 갖 는 반면 높은 이온전도도, 치밀막의 순수 이온전도성을 가져야 한다. 상용화 개발 단계의 $\mathrm{SOEC}$ 와 $\mathrm{SOFC}$ 는 대 부분 YSZ 전해질 소재를 채택하고 있으며, 단위 셀의 기계적 지지구조 형태에 따라 Table 1에서와 같이 전해 질지지형 (ESC; Electrolyte Supported Cell)과 음극 (SOFC)지지형 (ASC; Anode Supported Cell)으로 구 분되어 각각 다른 제조공정과 특징을 가지고 있다. 최근 $\mathrm{SOEC}$ 의 경우 내구성 확보를 위해 전극 지지형 타입보 다는 전해질 지지형 타입의 단위 셀을 채택하는 경우가 많아 고성능 이온 전도성 전해질 소재 또는 초 박판의 고강도 전해질 소재와 제조 공정에 관련된 연구들이 주 목을 받고 있다. $\mathrm{SOEC}$ 의 안정성을 확보하기 위해서는
촉매, 전극과 금속 분리판 등의 주변 소재 부품 기술 확 보가 중요하나, 현재까지는 $\mathrm{SOFC}$ 의 구성 소재 부품 기 술과 영역을 공유하고 있으며 수전해 반응에서 장시간 안정성과 내구성을 확보하기 위한 전극 소재에 대한 연 구가 활발하게 보고되고 있다.

$\mathrm{ZrO}_{2}$ 기반의 전해질을 $\mathrm{ESC}$ 형태로 제품화하는 경우 내구성은 우수하지만 여전히 상대적으로 낮은 출력성능 이나 수소 변환 성능의 단점이 있어 이온 전도성이 우 수한 소재 기술이 최근 주목받고 있다. SOEC의 경우 $\mathrm{SOFC}$ 보다 장시간 기계적, 화학적 안정성이 더 중요하 게 요구됨에 따라 우수한 이온 전도 특성과 기계적 강도 를 갖춘 $\mathrm{ESC}$ 형태의 $\mathrm{SOEC}$ 기술 개발은 매우 중요한 기 술 이슈가 될 것이다. $\mathrm{SOFC}$ 의 경우 (미)Bloom Energy 사는 $\mathrm{ESC}$ 제품 제조공정의 단순화를 통해 단위 셀의 대 량생산이 용이한 점을 강점으로 발전용 연료전지 시장 에서 확장성이 우수함을 증명하고 있으며, 또한 $\mathrm{ESC}$ 전 해질의 안정성으로 동일 SOFC 시스템으로 $\mathrm{SOEC}$ 수소 생산 시장까지 진출하고자 준비를 하고 있다.

Table 1. Comparison of cell configuration between ASC and ESC

\begin{tabular}{c|c|c}
\hline \multirow{2}{*}{ 구분 } & \multicolumn{1}{c}{$\begin{array}{c}\text { 음극지지형 } \\
\text { (ASC: Anode Supported Cell) }\end{array}$} & \multicolumn{1}{c}{$\begin{array}{c}\text { YSZ 기반 전해질지지형 } \\
\text { (ESC: Electrolyte Supported Cell) }\end{array}$} \\
\hline \multirow{2}{*}{ 특징 } & - 얇은 전해질로 인한 높은 성능 & - 두꺼운 전해질로 인해 낮은 성능 \\
& - 첨단 세라믹 공정기술 적용 필요 & - 새로운 고전도 소재 적용이 필수 \\
& - 음극 소재의 제한성으로 낮은 내구성 & - 기계적 고강도로 인한 높은 내구성 \\
\hline 생산성 & - 초기 첨단 생산설비 투자비용 발생 & - 대량 생산 용이, 공정 단순화 가능 \\
\hline 국내 상황 & - 국내외 연구개발 활발 & - 국내 연구개발 전무 \\
\hline
\end{tabular}

ASC : Anode Supported Solid Oxide Fuel Cell

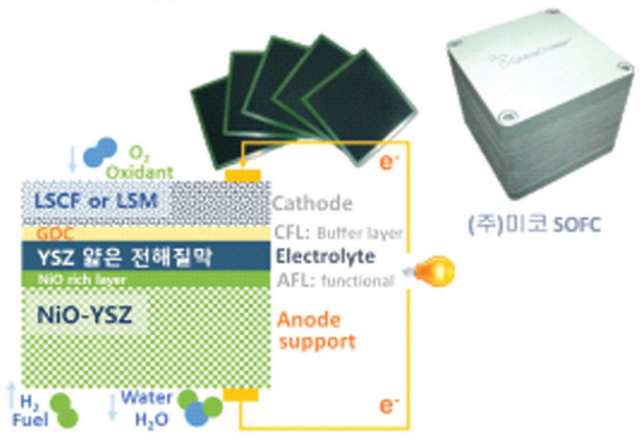

ESC : Electrolyte Supported Solid Oxide Fuel Cell

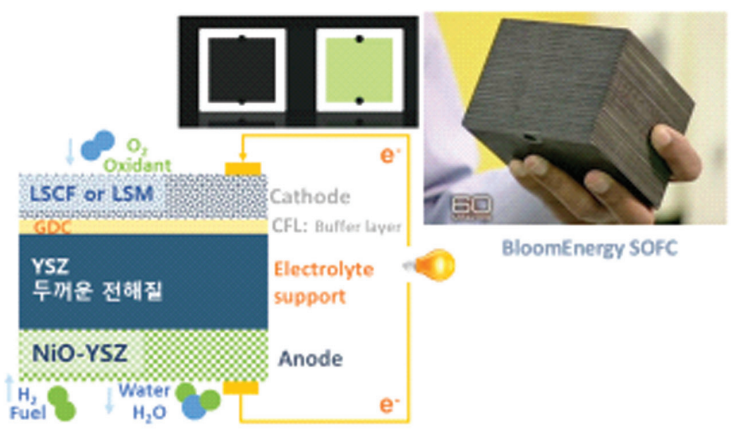

Fig. 4. Typical commercialization of ASC and ESC 


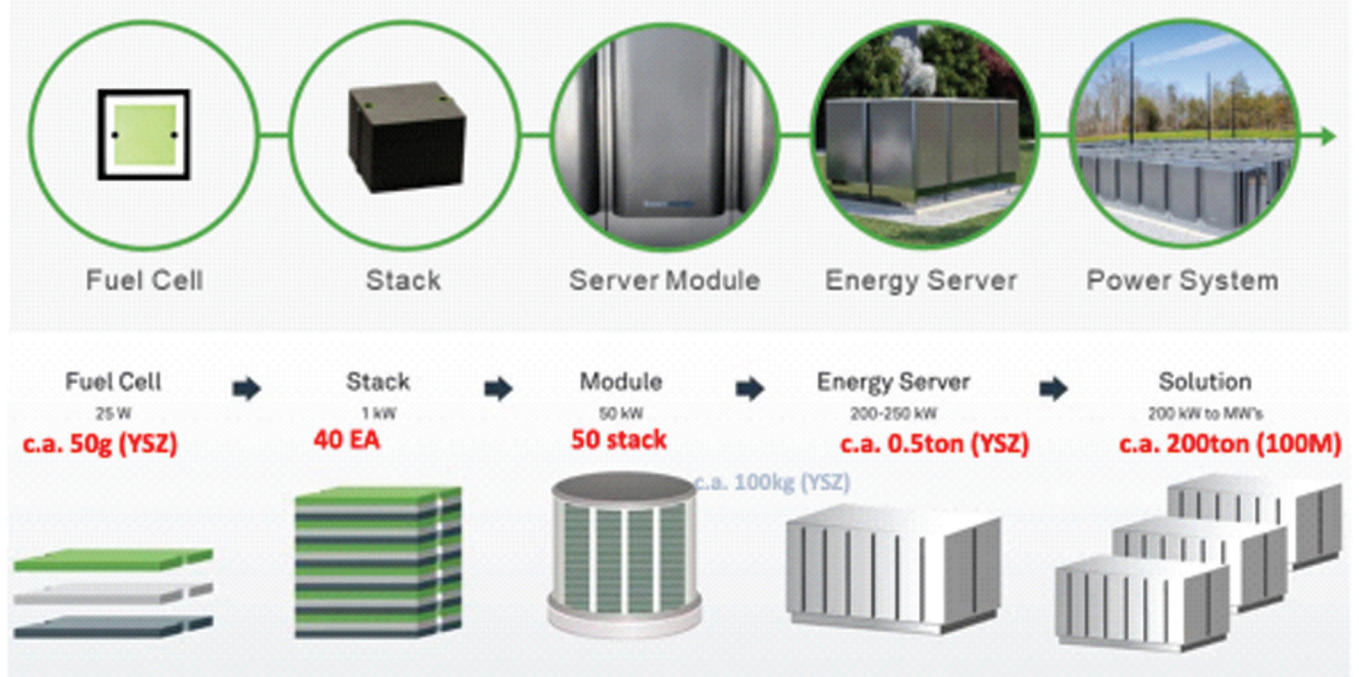

Fig. 5. ESC mass production of Bloom Energy company (www.bloomenergy.com)

\section{5. $\mathrm{LaGaO}_{3}$ 계 고 이온 전도성 전해질 소재}

$\mathrm{SOEC}$ 에 사용 가능한 전해질 소재로는 앞서 언급한 $\mathrm{YSZ}$ 소재가 있으며, 같은 $\mathrm{ZrO}_{2}$ 계 전해질로 $\mathrm{YSZ}$ 보다 이온전도성이 우수한 Sc stabilized zirconia (ScSZ)도 널리 사용되고 있다. (미)Bloom Energy 사의 $\mathrm{SOFC} /$ $\mathrm{SOEC}$ 는 $\mathrm{ESC}$ 형태의 단위 셀을 평판형으로 적층한 스 택 부품을 채택하고 있으며 $\mathrm{ScSZ}$ 계열의 고 이온 전도 성 전해질을 사용하여 안정적인 $\mathrm{SOFC}$ 와 $\mathrm{SOEC}$ 상업화 를 실현하고 있다. ScSZ계 전해질이 우수한 이온전도 성이 있지만 상용 시스템 구동 온도 감소에 큰 영향을 미치지 않기 때문에 (독)Sunfire 사 등 유럽의 일부 연 구자들은 ScSZ계 전해질의 우수한 성능보다는 전기화 학적 안정성 확보를 우선적 연구 관점으로 접근하여 초 박판 3YSZ (3mol\% Yttria doped zirconia)를 전해질 로 활용하는 연구결과들을 종종 보고하고 있다 $(3,4,6)$. $3 \mathrm{YSZ}$ 은 $8 \mathrm{~mol} \%$ 도핑된 $8 \mathrm{YSZ}$ 소재보다 이온전도성이 매우 낮으나 기계적인 강도가 우수하여 구조 세라믹 소 재로 널리 활용되는 소재이지만, $90 \mu \mathrm{m}$ 두께 이하의 박 판형 전해질 지지체를 사용할 경우 $\mathrm{ESC}$ 형태의 $\mathrm{SOEC}$ 의 구동이 가능한 것으로 Leon 등이 보고한 바 있다 (4). $\mathrm{SOEC}$ 스택이 $3 \mathrm{YSZ}$ 전해질을 사용한 경우 $830^{\circ} \mathrm{C}$
에서 $1.3 \mathrm{~V}$ 로 4000 시간 이상 구동하며 8000회 이상의 on/off 실험과 SOFC-SOEC 양방향 운전 사이클 등의 운전이 가능하였고 종합적으로 열화율 $0.8 \% / \mathrm{kh}$ 의 매우 우수한 내구성을 달성하였다 $(3,4)$. 하지만, $\mathrm{ZrO}_{2}$ 계 전 해질은 $\mathrm{ECS}$ 형태의 $\mathrm{SOEC}$ 에서 여전히 $800^{\circ} \mathrm{C}$ 이상의 고 온 작동이 필수적이며 도핑 원소의 튜닝을 통한 이온 전 도도 향상이나 전해질 지지체의 두께를 감소시켜야 하 는 연구 등이 지속적으로 수행되고 있다.

따라서, $\mathrm{SOFC} / \mathrm{SOEC}$ 의 금속 주변 부품 및 스택의 내 구성 확보를 위해 새로운 고 이온 전도성 전해질 소재를 개발하기 위해 세계적으로 90 년대 활발한 연구활동이 있었으며, 노벨상 수상자인 John B. Goodenough 교수 와 Tatsumi Ishihara 교수가 1994년 발표한 $\mathrm{Sr}, \mathrm{Mg}$ 도 핑 $\mathrm{LaGaO}_{3}$ 페롭스카이트 $\left(\mathrm{LSGM} ; \mathrm{La}(\mathrm{Sr}) \mathrm{Ga}(\mathrm{Mg}) \mathrm{O}_{3}\right)$ 는 일반적으로 YSZ 보다 5 배 이상의 높은 이온전도도 특 성을 갖고 있어 $800^{\circ} \mathrm{C}$ 이하 중저온 $\mathrm{SOFC}$ 소재로 주목 을 받아왔다. 산소 이온 전도 특성을 갖는 페롭스카이트 $\mathrm{ABO}_{3}$-type의 고체산화물 전해질은 $\mathrm{A}$-site에 3+ 이온 반경이 비교적 큰 La과 $\mathrm{B}-$ site에 $3+\mathrm{Ga}$ 으로 배치된 결 정구조를 가지고 있다. 비교적 이온 반경이 작은 $\mathrm{B}-$ site 의 경우 산소 이온과 6 배위수로 결합되어 팔면체 구조 체가 되며 A 원소 주위를 둘러싸게 되고 A-site는 주변 


\section{특 집 묘 이석희, 이상원, 김수지, 신태호}

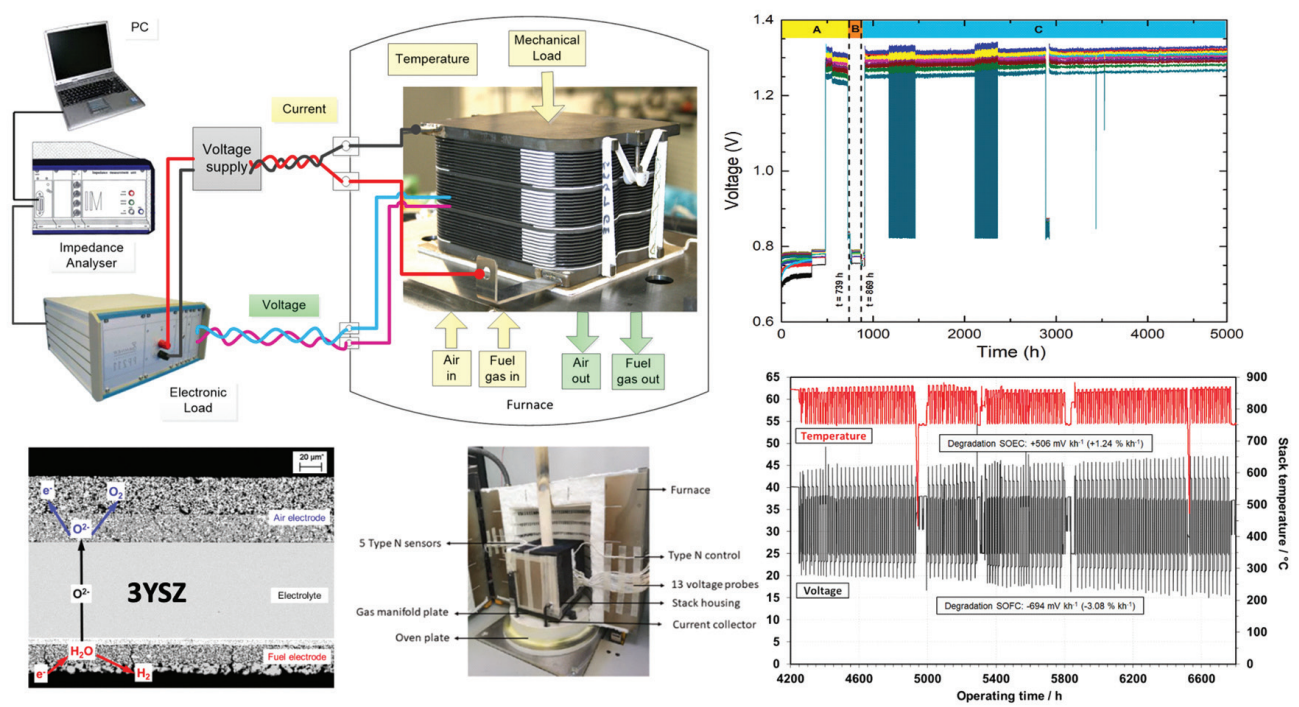

Fig. 6. SOEC stack operation results of Sunfire GmbH using 3YSZ electrolyte reproduced from Lang et al. Fuel cells. 2020;20:690700, with permission of John Wiley \& Sons Ltd. Press, Léon et al. J. Power Sources. 2021;510:230346, with permission of Elsevier BV Press $(3,4)$

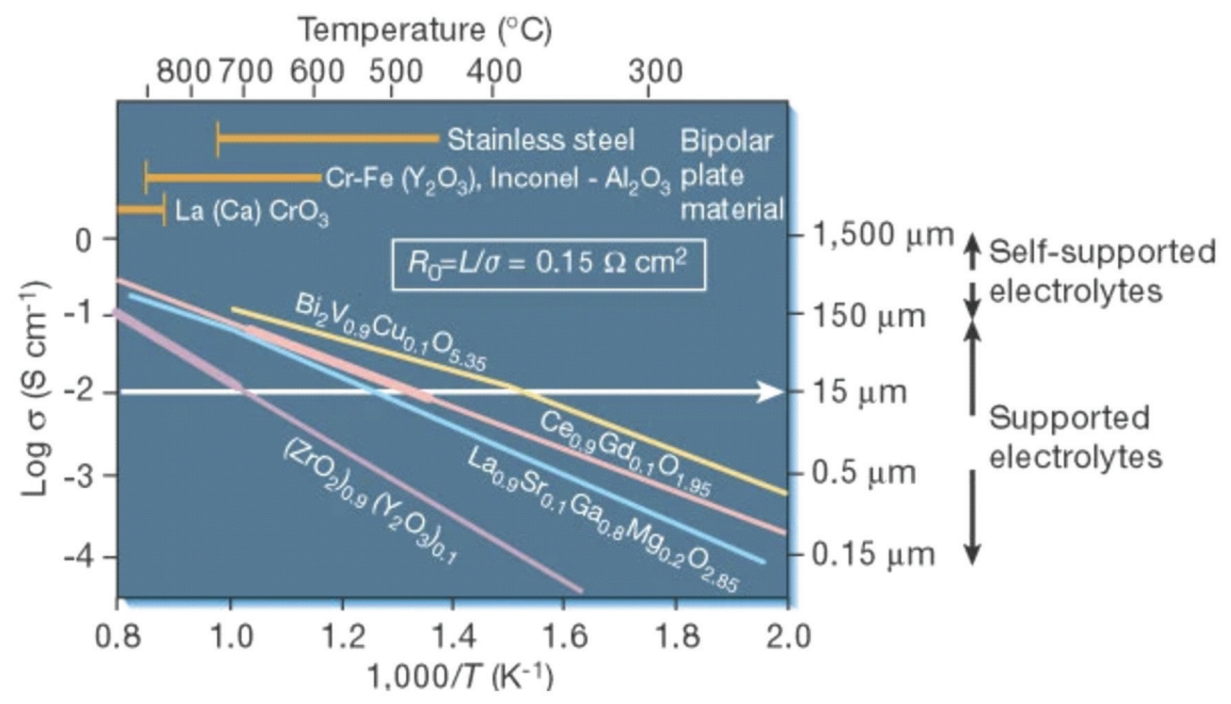

Fig. 7. LSGM electrolyte conductivity comparing with other oxides adapted from Steele et al. Nature 2001;414:345-352, with permission of Nature Publishing Group Press (7)

산소 이온과 12 배위수로 연결되어 있다. 이러한 산소 이 온 팔면체 구조와 A-site 12 배위수 결합은 결정구조 내 에서 전자전도성을 만들 수 있는 전자가 보상이 없는 범 위에서 높은 산소 공공이 형성될 경우 산소 이온 내부 이동 경로와 에너지가 낮아져 비교적 높은 산소 이온 전 도 특성을 나타내게 된다. (5) LSGM의 전도도의 경우 소
량의 $\mathrm{Co}$ 를 $\mathrm{B}-\mathrm{site}$ 에 추가적으로 도핑 함으로써 일정 전 도도의 향상이 보고되기도 하였으나, 다양한 구성성분 의 화학적 안정성 문제로 고온의 단위 셀 제조공정이나 장시간 고온 노출에 따른 $\mathrm{Ga}$ 의 휘발 손실 등의 가능성 으로 원하지 않는 이차 상의 생성으로 전도도의 열화가 생길 수 있는 위험성이 있다. A/B site의 조성의 비율 


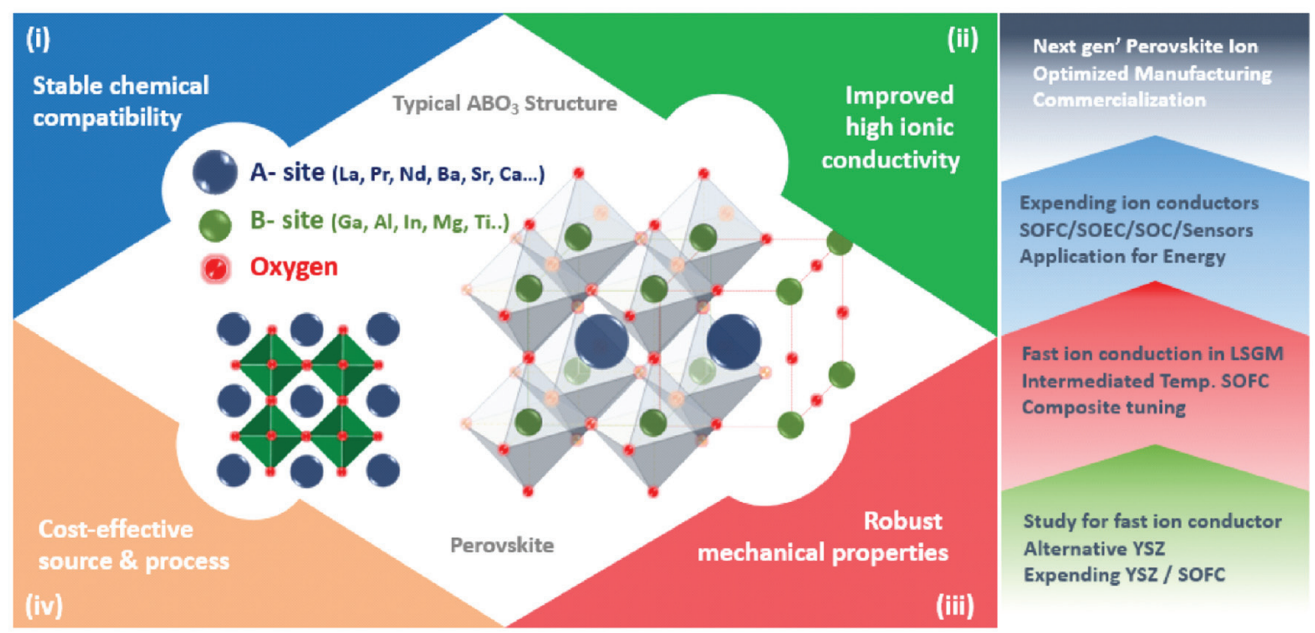

Fig. 8. Perovskite ion conductor $\mathrm{ABO}_{3}$ typical structure and the requirements faced in the roadmap adapted from Irvine et al JPhys Energy 2021;3:031502, with permission of IOP Publishing Press (8)

제어를 통한 $\mathrm{LaGaO}_{3}$ 에서의 $\mathrm{Ga}$ 고온 휘발 특성에 대한 연구가 일부 진행되었으나 다양한 조성비와 첨가 원소 에 따른 영향에 대한 연구가 수반될 필요가 있다.

최근에는 이러한 LSGM의 사용의 한계성을 극복하고 자 다양한 상용화 기술이 개발 중에 있으며 산업에 적용 이 가능한 수준의 이차 상 반응 방지 코팅 기술, 페롭스 카이트 조성 안정화 기술, 저가 제조공정 기술 및 기계 적 강도 향상 기술 등이 향후 문제점 해결 기술 로드맵 (Fig. 8.)으로 제시되어 SOFC는 물론 $\mathrm{SOEC}$ 에도 중저 온용 전해질로 활용되고 있다 (8).

\section{6. $\mathrm{LaGaO}_{3}$ 계 전해질을 적용한 SOEC 최신기술}

LSGM을 이용한 고온 수전해에 대한 연구는 2000년 대부터 시작되었으며, Ishiahra 교수와 Kanno 연구자가 2010년에 $\mathrm{Ni}-\mathrm{Fe}$ 합금 cathode와 $\mathrm{Ba}(\mathrm{La}) \mathrm{CoO}_{3}$ anode 를 이용하여 $600^{\circ} \mathrm{C}$ 와 $800^{\circ} \mathrm{C}$ 에서 운전하여 $82 \%$ 의 전기 효율로 수소 생산을 성공적으로 보고한 바 있다. 보고에 따르면 $1.8 \mathrm{~V}$ 운전전압에서 $280 \mathrm{mmol} / \mathrm{cm}^{2} \min (0.9 \mathrm{~A} /$ $\mathrm{cm}^{2}$ )의 수소 생산 $82.3 \% \mathrm{LHV}$ 전기효율을 기록하였으 며 손실 전기효율은 면적당 $I^{2} R=0.89 \mathrm{~J} / \mathrm{cm}^{2}$ 으로 Joule heating을 분석 보고하였다(9).
이후 많은 연구그룹들은 cathode 전극의 촉매적 기 능 강화나 전극 내구성 향상을 위한 새로운 소재 개발과 적용으로 $\mathrm{LSGM}$ 계 $\mathrm{SOEC}$ 성능을 향상시키고 있다. F. Chem 교수는 $\mathrm{Sr}_{2} \mathrm{Fe}_{1.3} \mathrm{Ni}_{0.2} \mathrm{Mo}_{0.5} \mathrm{O}_{6}$ 의 층상구조 더블 페 롭스카이트 산화물 소재를 기존 보고된 LSGM계 SOEC 의 cathode $\mathrm{Ni}-\mathrm{Fe}$ 대신 적용하여 $850^{\circ} \mathrm{C} 1.3 \mathrm{~V}$ 구동에서 수소 변환 생산 $1.26 \mathrm{~A} / \mathrm{cm}^{2}$ 의 높은 전류밀도를 기록, 보고하였다 (Fig. 10.). 고온에서 $\mathrm{SOEC}$ 구동을 통해 더 블 페롭스카이트 결정구조 내부의 $\mathrm{Ni}$ 을 in-situ 용출법 으로 표면에 나노구조를 형성함으로 성능의 향상이 됨 을 보고하였다(10). Guntae Kim 교수는 산소 저장능이 있는 $\mathrm{PrBa}_{0.5} \mathrm{Sr}_{0.5} \mathrm{Co}_{1.5} \mathrm{Fe}_{0.5} \mathrm{O}_{5+}$ 더블 페롭스카이트 산화 물 전극을 활용하여 매우 우수한 성능의 $\mathrm{SOEC} / \mathrm{SOFC}$ 양방향 운전을 구현하였으며, SOEC의 경우 Fig. 11.에 서와 같이 $800^{\circ} \mathrm{C} 1.3 \mathrm{~V}$ 구동에서 600 시간 동안 심각한 열화 현상 없이 수소 변환 생산 $1.31 \mathrm{~A} / \mathrm{cm}^{2}$ 의 높은 전 류밀도를 기록하였다 (11).

최근에는 LSGM의 장점을 최대한 활용하기 위하여 tubular type의 음극지지체에 LSGM 전해질을 얇은 막 으로 코팅하여 $600^{\circ} \mathrm{C}$ 이하 범위의 중저온에서의 고성 능의 수전해 특성 향상에 대한 연구들이 진행되고 있다 $(12,13) . \mathrm{LSGM}$ 전해질을 활용하여 전기화학적으로 안 정적인 고성능 전류밀도를 얻기 위해서는 LSGM 전해질 


\section{특 집}

a.

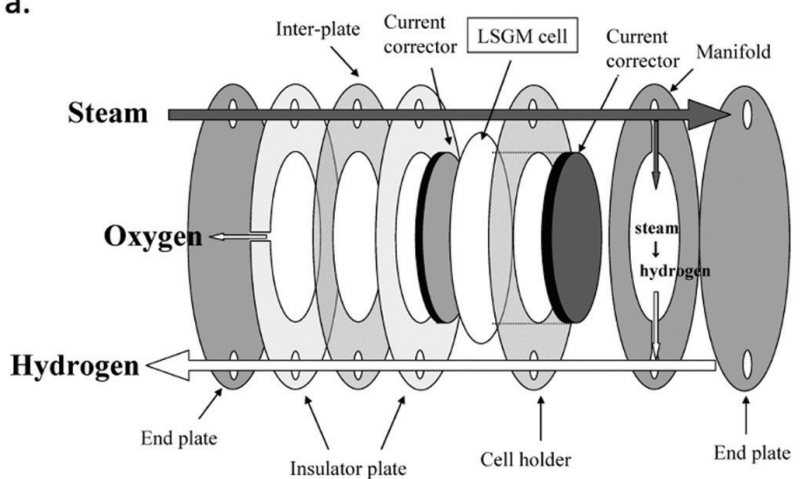

b. $\phi 84 \mathrm{~mm}$ (excepting terminal)

ca. $80 \mathrm{~mm}$

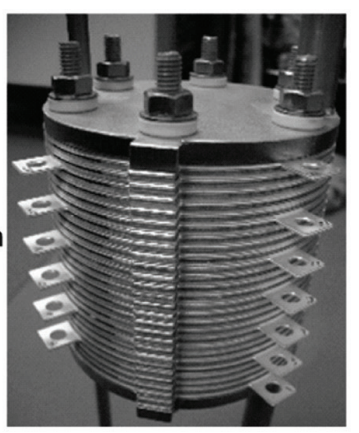

c.

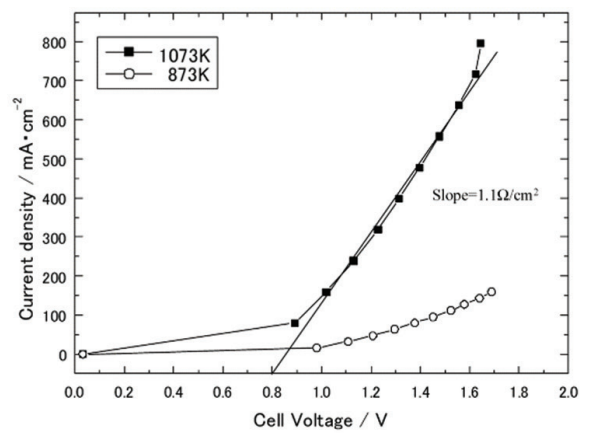

d.

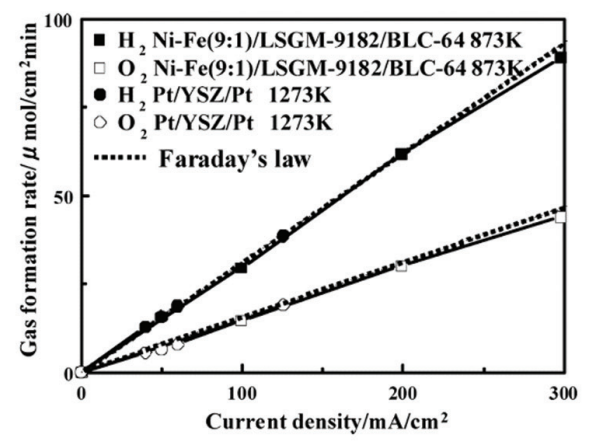

Fig. 9. (a)Scheme of the SOEC stack using LSGM cell, (b) Photographs of stacks, (c) I-V performance of SOEC using LSM cell,

(d) Comparison of $\mathrm{H}_{2}$ formation rate on the cell using LSGM with $\mathrm{Ni}-\mathrm{Fe}$ and Pt electrode adapted from Ishihara et al. ISIJ Int. 2010;50:1291-5, with permission of The Iron and Steel Institute of Japan Press (9)

과 전극 계면 사이의 불순물 반응, 기계적 특성 불일치 등의 문제점들을 제조공정 단계에서 해결해야 하며 이 를 위하여 $\mathrm{CeO}_{2}$ 계의 혼합 전도성 물질을 중간 기능층으 로 활용하여 계면에서의 기계적, 전기화학적 열화 특성 을 제어하는 연구들이 활발히 이루어지고 있다. 하지만, $\mathrm{LSGM}$ 전해질 지지형의 $\mathrm{SOEC}$ 전기화학적 성능에 비해 여전히 월등히 높지 않으며 이는 고온에서의 전극 소결 공정에서 계면에서의 부반응을 완벽히 억제하지 못했기 때문이며 향후 이러한 LSGM 계면에서의 부반응 문제를 해결하기 위한 연구들이 지속적으로 필요하다.

LSGM은 다양한 페롭스카이트 산화물 전극과의 호환 성으로 수소 생산의 고온 수전해 연구뿐만 아니라 이산 화탄소 $\left(\mathrm{CO}_{2}\right)$ 를 고온에서 전기화학적으로 분해하는 전 해 셀에도 전해질로 적용되고 우수한 성능으로 보고되 고 있다. S. Lee, M. Kim 등의 연구자들은 LSGM 전
해질과 호환되는 $\mathrm{La}(\mathrm{Sr}) \mathrm{Cr}(\mathrm{Mn}) \mathrm{O}_{3}$ 페롭스카이트 산화물 cathode 전극 표면 위에 $\mathrm{CeO}_{2}$ 계 촉매로 전극 표면에 산 소공공을 증강시켜 이산화탄소의 전기화학적 반응을 극 대화함으로 $850^{\circ} \mathrm{C} 1.5 \mathrm{~V}$ 구동에서 이산화탄소 변환 생산 $2.64 \mathrm{~A} / \mathrm{cm}^{2}$ 의 높은 전류밀도를 보고하였다(14). 이러 한 기능성 페롭스카이트 전극이 적용된 LSGM 전해질 셀은 수소 생산 $\mathrm{SOEC}$ 구동에서도 높은 수소 생산 효율 을 나타낼 수 있는 단위 셀 구성으로 적용될 것이다.

\section{7. $\mathrm{LaGaO}_{3}$ 계 전해질 부반응 억제 기술 동향}

앞서 살펴본 바와 같이 $\mathrm{LaGaO}_{3}$ 계 전해질은 다양 한 새로운 전극 소재를 적용하여 중저온에서 우수한 $\mathrm{SOFC} / \mathrm{SOEC}$ 성능을 보여주고 있다. 하지만, 여전히 $\mathrm{LaGaO}_{3}$ 계 소재의 고온 제조 공정에서의 화학적 안정 
a.

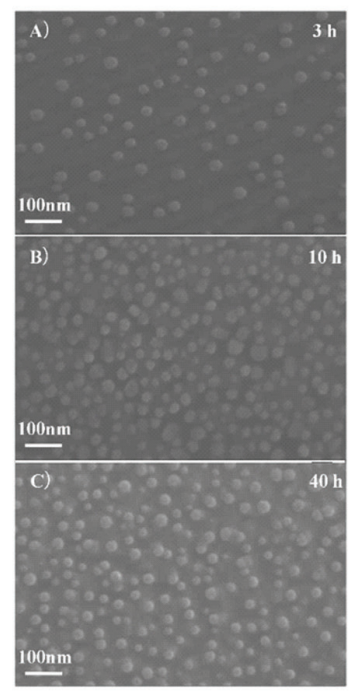

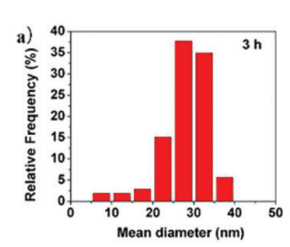
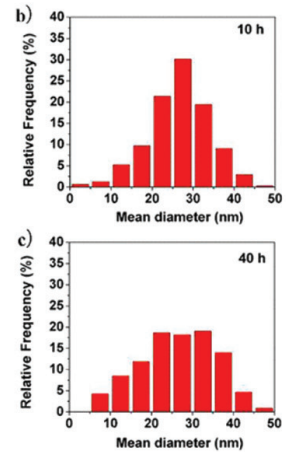

b.

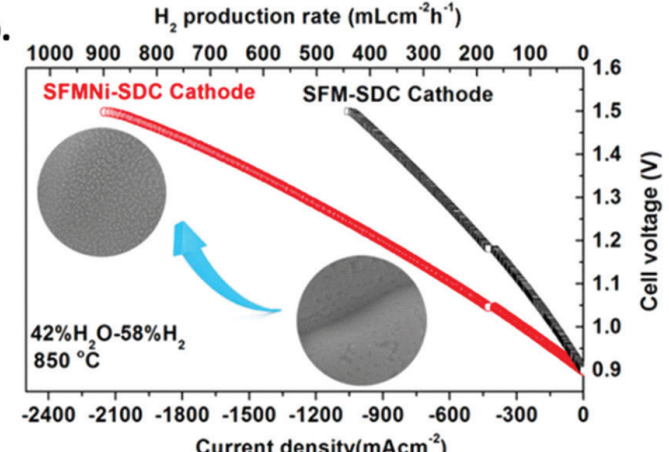

c.

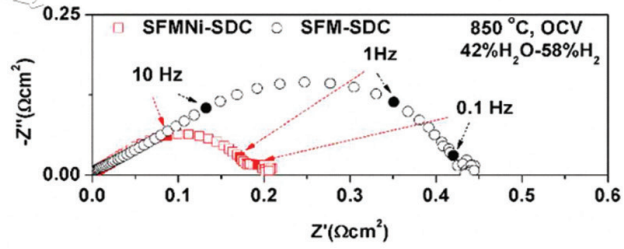

Fig. 10. (a) Surface morphology of Ni exsolution, (b) I-V curves under SOEC operation, (c) impedance of SOEC cell adapted from Wang et al. J. Mater. Chem. 2016;4:14163-14169, with permission of Royal Society of Chemistry Press (10)
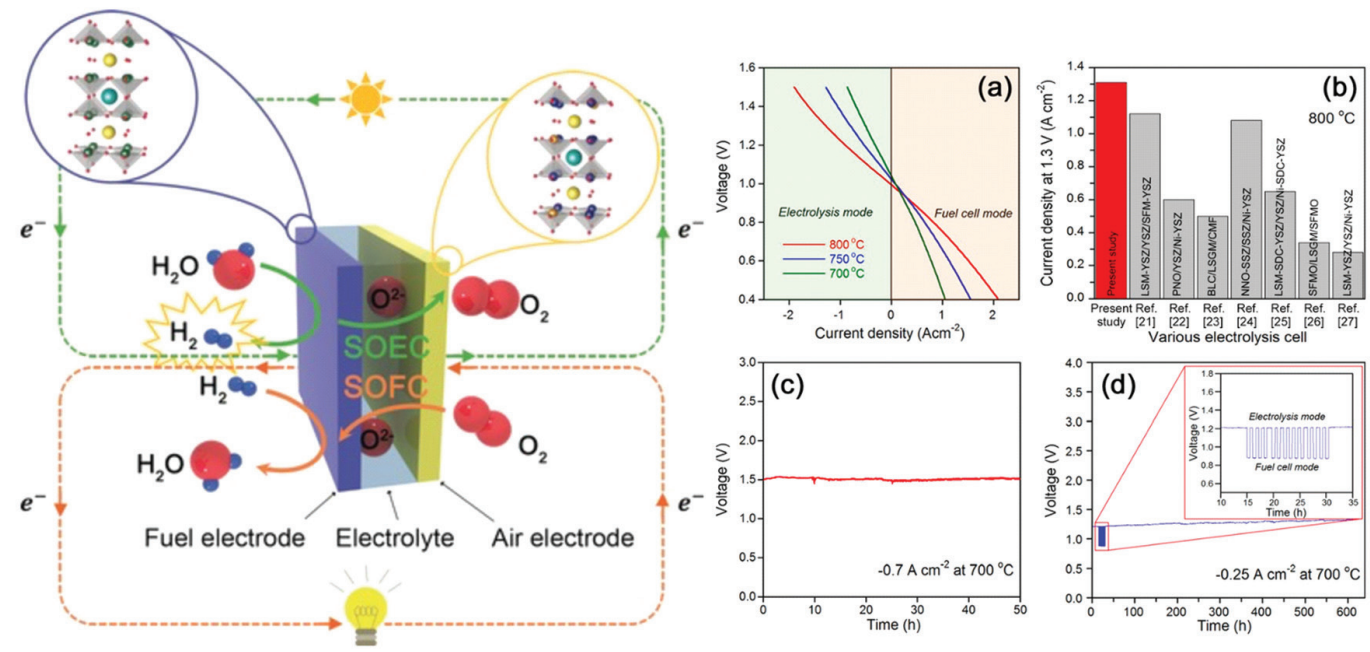

Fig. 11. (a) Scheme of LSGM SOC(reversible solid oxide cells), (b) Superior (11) electrochemical performance of PBSCF/YSZ/PBSCF adapted from Jun et al. Angew. Chem. Int. Ed. 2016;55:12512-12515, with permission of John Wiley \& Sons Ltd. Press

성을 확보하는 것에 한계가 있으며 이를 극복하기 위하 여 전해질 계면에서의 이온 전도 성능저하 없이 부반응 을 억제하는 기능층 코팅막에 대한 연구가 필요하다. 새 로운 전극 물질을 저온에서 도포하여 제조하여 단위 셀 평가 실험은 가능하지만, 상용화의 수준에서는 대량의 전극 도포 과정을 위해 $1000^{\circ} \mathrm{C}$ 이상의 고온 소결 공정
이 필수이며 이러한 고온 소결 공정에서 전극 물질과 부 반응 억제를 위해 많은 연구자와 개발자들은 $\mathrm{CeO}_{2}$ 계 기 능층을 표면에 도포하여 사용하고 있다. 이온전도성이 우수한 LSGM 표면에 기능층을 코팅하여 이온전도성 의 영향없이 범위에서 우수한 전기화학적 성능을 구현 하기 위해 최적 막의 두께와 미세구조 제어 연구를 $\mathrm{K}$. 


\section{특 집 ㅍㅃ 이석희, 이상원, 김수지, 신태호}
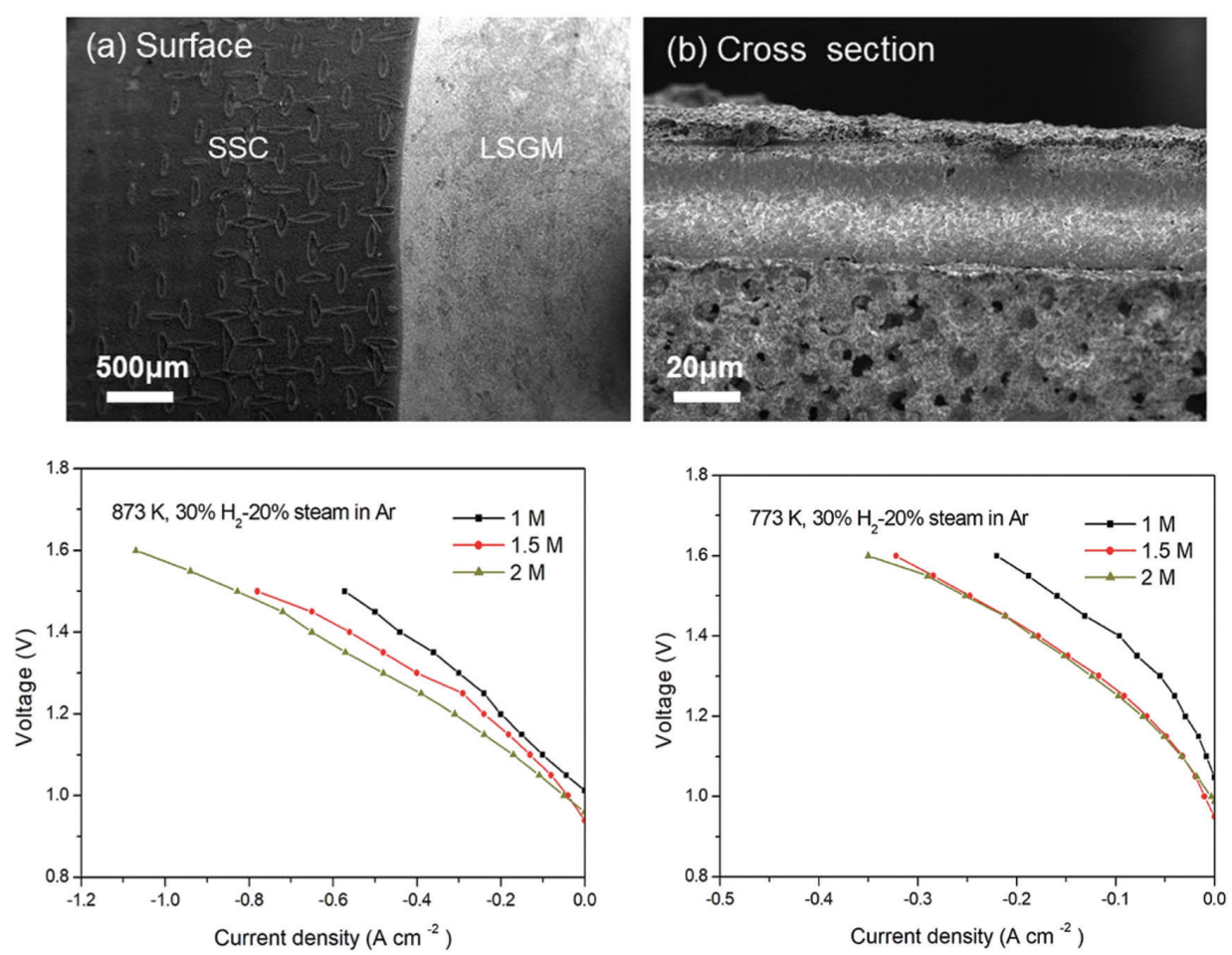

Fig. 12. SEM images of tubular anode supported type LSGM SOEC cell and their I-V performance adapted from Tan et al. J. Mater. Chem. 2021:9:1530-1540, with permission of Royal Society of Chemistry Press (12)

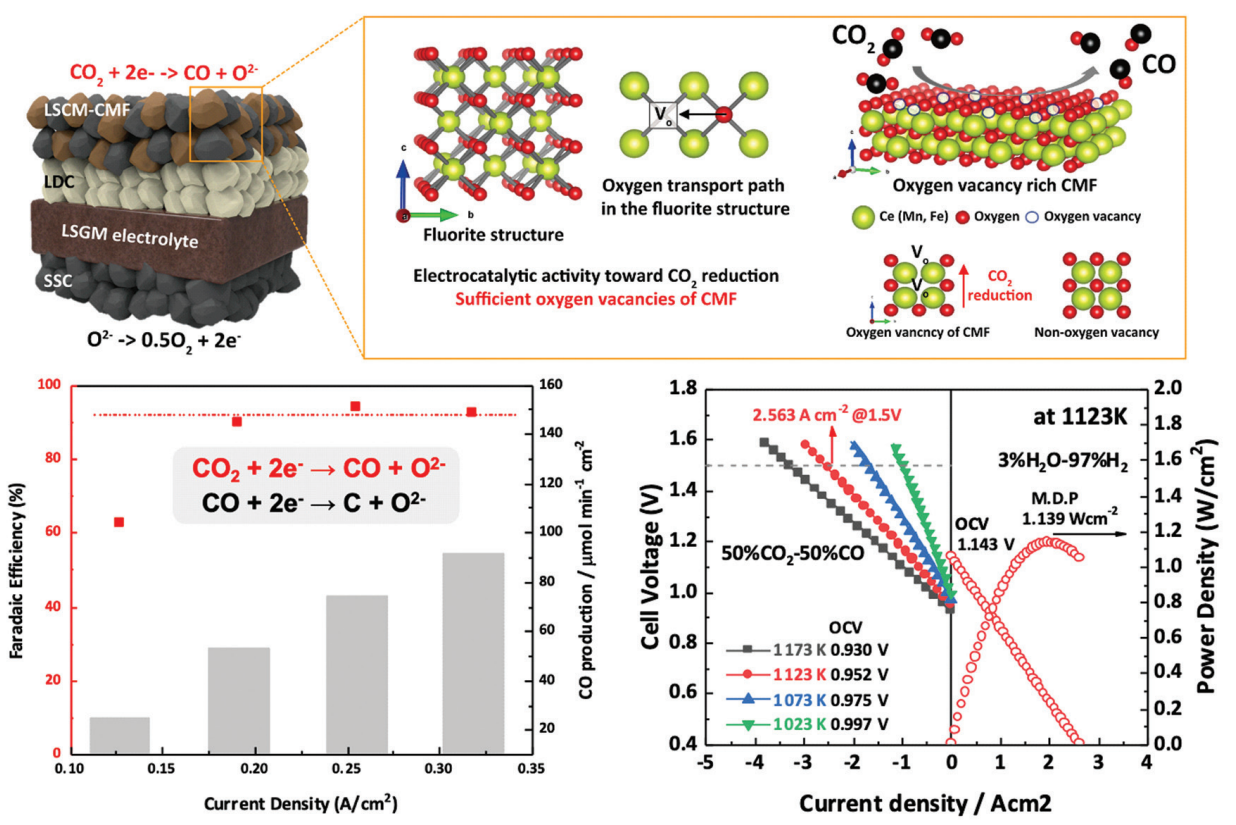

Fig. 13. The effect of La doped Ceria, functional coating buffer layer on protecting secondary phase between LSGM and Ni based anode adapted from Hwang et al, J. Eur. Ceram. Soc 2021;41:2674-2681, with permission of Elsevier BV Press (13) 
(a)

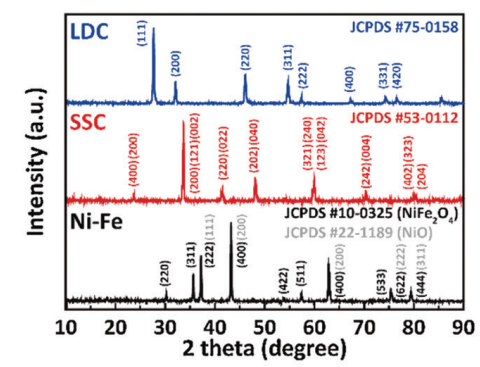

(c)

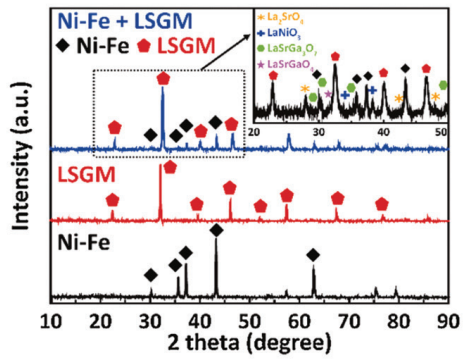

(b)

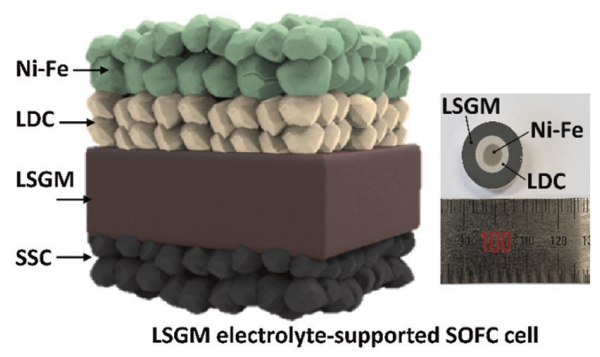

(d)

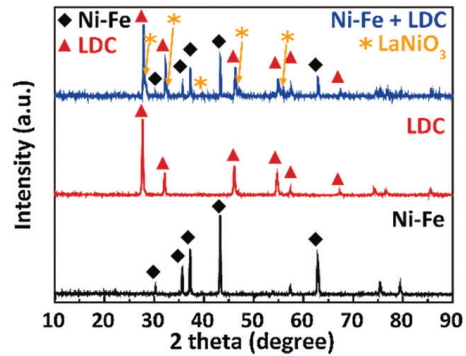

Fig. 14. The effect of La doped Ceria, functional coating buffer layer on protecting secondary phase between LSGM and Ni based anode adapted from Hwang et al, J. Eur. Ceram. Soc 2021;41:2674-2681, with permission of Elsevier BV Press (13)

Hwang, T. H. Shin 등의 연구자들은 발표하였으며, 스크린 프린팅 기법으로 $20 \mu \mathrm{m}$ 두께 내외에서 최적 전 기화학 성능을 보고하였고 보다 얇은 막에서 최적화를 위한 제조공정 기법과 미세구조와 두께에 따른 연구를 지속 수행 중에 있다.

\section{8. 결론}

본 논문에서는 수소 생산용 차세대 수전해 기술인 고 온 수전해 기술에 대한 배경지식과 더불어 최근 활발하 게 연구되고 있는 고 이온 전도 특성의 페롭스카이트 전 해질 $\mathrm{LaGaO}_{3}$ 계 소재에 대하여 체계적으로 정리하고 페 롭스카이트 전해질이 적용된 $\mathrm{SOEC}$ 의 최신 기술동향에 살펴보았다. $\mathrm{LaGaO}_{3}$ 계 전해질 소재는 전해질 지지형으 로 고성능 $\mathrm{SOFC}$ 출력밀도, $\mathrm{SOEC}$ 전류밀도 구현이 가 능하여 최근 크게 주목받고 있는 원천 소재 기술이며, 다양한 기능성 페롭스카이트 산화물 전극과의 호환성으 로 전극 표면에서의 촉매 활성화, 분자 흡탈착 반응 제
어 등이 가능하여 고온 전기분해 공정으로 고효율의 수 소 생산은 물론 이산화탄소 분해 제거까지 가능한 기술 이다. 관련하여 많은 응용 연구들이 이루어지고 있지만, $\mathrm{LaGaO}_{3}$ 계 소재에 대한 기초적 연구의 확장과 대체적인 고 이온 전도성 물질의 개발이 부족하며 $\mathrm{LaGaO}_{3}$ 계의 $\mathrm{SOFC}$ 적용 연구에 비하여 $\mathrm{SOEC}$ 적용 연구는 여전히 부족하다. 또한 $\mathrm{LaGaO}_{3}$ 계 적용 $\mathrm{SOFC} / \mathrm{SOEC}$ 의 상업화 를 위하여 제조공정에서의 부반응 억제, 장시간 운전에 서의 화학적 안정성에 대한 연구도 동시에 수반되어야 하며, 추후에는 이러한 기술개발에 관한 심층적인 연구 가 더욱 활발히 진행되길 기대한다.

\section{감사의 글}

본 연구는 산업통상자원부와 한국산업기술진흥원이 지원하는 국제공동기술개발사업으로 수행된 연구결과 (P0004433)이며, 한국에너지기술평가원의 지원을 받아 수행된 연구(20203030030070)입니다. 


\section{REFERENCES}

1. F. M. Sapountzi, J. M. Gracia, C. J. Weststrate, H. O. A. Fredriksson, J. W. Niemantsverdriet, "Electrocatalysts for the generation of hydrogen, oxygen and synthesis gas," Progress in Energy and Combustion Science, 58, 1-35 (2017).

2. M. A. Laguna-Bercero, "Recent advances in high temperature electrolysis using solid oxide fuel cells: A review," Journal of Power Sources, 203, 4-16 (2012).

3. M. Lang, S. Raab, M. S. Lemcke, C. Bohn, M. Pysik, "Long-Term Behavior of a Solid Oxide Electrolyzer (SOEC) Stack," Fuel Cells, 20, [6], 690-700 (2020).

4. A. Léon, A. Micero, B. Ludwig, A. Brisse, "Effect of scaling-up on the performance and degradation of long-term operated electrolyte supported solid oxide cell, stack and module in electrolysis mode," Journal of Power Sources, 510, 230346 (2021).

5. J. H. Park, D. Kim, K. J. Kim, K. T. Bae, K. T. Lee, "고성능 고체산화물 연료전지를 위한 이중층 전해질 전략”, Ceramist, 23, [2], 184-199 (2020)

6. A. Masini, T. Strohbach, F. Šiška, Z. Chlup, I. Dlouhý, "Electrolyte-Supported Fuel Cell: Co-Sintering Effects of Layer Deposition on Biaxial Strength," Mater., 12, [2], 306 (2019).

7. B. C. H. Steele, A. Heinzel, "Materials for fuel-cell technologies," Nature, 414, 345-352 (2001).

8. J. Irvine, J. L. M. Rupp, G. Liu, X. Xu, S. Haile, X. Qian, A. Snyder, R. Freer, D. Ekren, S. Skinner, O. Celikbilek, S. Chen, S. Tao, T. H. Shin, R. O'Hayre, J. Huang, C. Duan, M. Papac, S. Li, V. Celorrio, A. Russell, B. Hayden, H. Nolan, X. Huang, G. Wang, I.
Metcalfe, D. Neagu and S. G. Martín "Roadmap on inorganic perovskites for energy applications," Journal of Physics: Energy, 3, [3], 031502 (2021).

9. T. Ishihara, T. Kanno, "Steam Electrolysis Using $\mathrm{LaGaO}_{3}$ Based Perovskite Electrolyte for Recovery of Unused Heat Energy," ISIJ International, 50, [9], 12911295 (2010).

10. Y. Wang, T. Liu, M. Li, C. Xia, B. Zhou, F. Chen, "Exsolved $\mathrm{Fe}-\mathrm{Ni}$ nano-particles from $\mathrm{Sr}_{2} \mathrm{Fe}_{1.3} \mathrm{Ni}_{0.2} \mathrm{Mo}_{0.5} \mathrm{O}_{6}$ perovskite oxide as a cathode for solid oxide steam electrolysis cells," Journal of Materials Chemistry A, 4, [37], 14163-14169 (2016).

11. A. Jun, J. Kim, J. Shin, G. Kim, “Achieving High Efficiency and Eliminating Degradation in Solid Oxide Electrochemical Cells Using High OxygenCapacity Perovskite," Angewandte Chemie International Edition, 55, [40], 12512-12515 (2016).

12. Z. Tan, J. T. Song, A. Takagaki, T. Ishihara, "Infiltration of cerium into a NiO-YSZ tubular substrate for solid oxide reversible cells using a LSGM electrolyte film," Journal of Materials Chemistry A, 9, [3], 1530-1540 (2021).

13. K. J. Hwang, M. Jang, M. K. Kim, S. H. Lee, T. H. Shin, "Effective buffer layer thickness of La-doped $\mathrm{CeO}_{2}$ for high durability and performance on $\mathrm{La}_{0.9} \mathrm{Sr}_{0.1} \mathrm{Ga}_{0.8} \mathrm{Mg}_{0.2} \mathrm{O}_{3-\delta}$ electrolyte supported type solid oxide fuel cells," Journal of the European Ceramic Society, 41, [4], 2674-2681 (2020).

14. S. Lee, M. Kim, K. T. Lee, J. T. S. Irvine, T. H. Shin, "Enhancing Electrochemical $\mathrm{CO}_{2}$ Reduction using $\mathrm{Ce}(\mathrm{Mn}, \mathrm{Fe}) \mathrm{O}_{2}$ with $\mathrm{La}(\mathrm{Sr}) \mathrm{Cr}(\mathrm{Mn}) \mathrm{O}_{3}$ Cathode for High-Temperature Solid Oxide Electrolysis Cells," Advanced Energy Materials, 11, [24], 2100339 (2021) 


\section{๑。 신 태호}

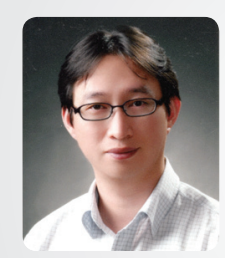

- 2006년 연세대학교 세라믹공학과 석사

0 2012년 Kyushu University 공학박사

○ 2006년-2007년 동부기술원 주임연구원

- 2012년-2015년 University of St Andrews, Research Fellow

( 2015년-2020년 한국세라믹기술원 선임연구원

- 2021년-현재 한국세라믹기술원 책임연구원/ $\mathrm{EEM}$ 센터장

\section{○. 이상 원}

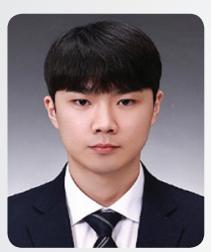

( 2019년 원광대학교 화학과 이학사

( 2020년-2021년 한국세라믹기술원 연수연구원

- 2021년 원광대학교 화학공학과 석사

( 2021년-현재 연세대학교 화공생명공학과 박사과정

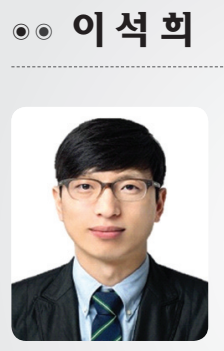

( 2013년 연세대학교 신소재공학과 박사

ㅇ 2014년-2016년 Auburn University, Research Fellow

( 2) 2016년-2018년 연세대학교 융합 기술원 연구원

( 2018년-현재 한국세라믹기술원 책임기술원

๑。 김수지

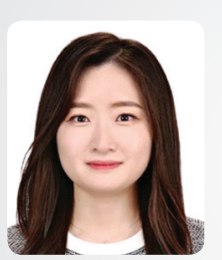

2021년 연세대학교 나노과학공학과 공학사

- 2021년-현재 한국세라믹기술원 인턴연구원 